\title{
How Ethics Failed - \\ The Role of Psychiatrists and Physicians in Nazi Programs from Exclusion to Extermination, 1933-1945
}

\author{
Jutta Lindert, PhD, MA, ${ }^{1}$ \\ Yael Stein, MD, ${ }^{2}$ \\ Hans Guggenheim, $\mathrm{PhD},{ }^{3}$ \\ Jouni J. K. Jaakkola, MD, DSC, PhD, ${ }^{4}$ \\ Rael D. Strous, $\mathrm{MD}^{5}$
}

\begin{abstract}
Background: Disregard of Hippocratic medical ethics by major leaders in the Public Health establishment and the leadership role played by physicians during the Nazi era in Germany (1933-1945) pose continuing challenges for later generations to investigate and disclose. Aims: We review the history of evolution from humiliation of mental patients, other ill and disabled individuals and targeted ethnic groups to humiliation, sterilization, and "involuntary euthanasia" (a euphemism for medical murder). We focus on the role played by psychiatrists and neurologists during the Nazi period in Germany; we discuss the ethical norms of universal dignity, compassion and responsibility and we propose concrete steps to prevent recurrence of medically supported genocide. Methods: We explored the history of psychiatry of the period leading up to, including and immediately after the Nazi era in order to analyze the ethical standards and practices of psychiatrists and neurologists. Results: Psychiatrists, and neurologists, were guilty leaders and participants in the implementation of the Nazi programs, which escalated from humiliation and classification of their victims to the exclusion of the mentally ill and disabled, to devaluation and forced sterilization, to medical murder, then finally to the industrialized mass murder of millions, named the "Final Solution". Discussion: This process was driven by a dangerous mix of failure of medical

\footnotetext{
${ }^{1}$ Protestant University of Applied Sciences Ludwigsburg, Ludwigsburg, Germany.

${ }^{2}$ Hebrew University - Hadassah Medical Center, Jerusalem, Israel.

${ }^{3}$ Founder, Foundation Guggenheim, Boston, United States.

${ }^{4}$ Center for Environmental and Respiratory Health Research, University of Oulu, Oulu, Finland.

${ }^{5}$ Sackler Faculty of Medicine, Tel Aviv University, Tel Aviv, Israel.
}

Corresponding Author Contact Information: Jutta Lindert at mail@jlindert.de; Paulusweg 6, 71638 Ludwigsburg, Germany. 
ethics, racist ideology and individual ambition. Radicalized myths of racial and genetic purity and $19^{\text {th }}$ century technology of industrial production transformed into a technology driven industry of mass murder; motivated by calculated ambitions and desire for individual career advancement. Post war, the Nuremberg Trials and later The Universal Declaration of Human Rights defined standards of ethical framework for the medical profession everywhere. Outlook: Each generation should be made aware of these events through awareness, education and communication to prevent recurrence of medical professional criminality.

Keywords: Psychiatry, Nazi euthanasia, sterilization, medical ethics, genocide, the Final Solution

Suggested Citation: Lindert J, Stein Y, Guggenheim H, Jaakkola JJK, von Cranach M, Strous RD. How ethics failed - the role of psychiatrists and physicians in Nazi programs from exclusion to extermination, 1933-1945. Public Health Reviews. 2013;34: epub ahead of print.

"We have been silent witnesses of evil deeds: we have been drenched by many storms; we have learnt the art of equivocation and pretense; experience has made us suspicious of others and kept us from being truthful and open; intolerable conflicts have worn us down and even made us cynical. Are we still of any use? What we shall need is not geniuses, or cynics, or misanthropes, or clever tacticians, but plain, honest,

straightforward men. Will our inward power of resistance be strong enough, and our honesty with ourselves remorseless enough, for us to find our way back to simplicity and straightforwardness?"

Dietrich Bonhoeffer ${ }^{1}$

\section{INTRODUCTION}

Prior to and during the National Socialist German Workers' Party, commonly known as the Nazi Party, regime in Germany (1933-1945), physicians were influenced by Social Darwinism, ideas of racial and genetic purity, and by the mythology of a superior race, and so abandoned their traditional medical ethical standards and fell into the seductive ideals of the eugenics movement. ${ }^{2-5}$ There can be no doubt about the role played by the medical profession in the planning and execution of the eugenics programs in Germany, and that opportunities for professional advancement played a major role in their participation. A body of scholarly work has been published about the complicity of physicians during the Nazi era, ${ }^{6-13}$ but the specific roles played by physicians and medical institutions during this period still demand in-depth investigation. ${ }^{10,14}$ In contrast, the criminal 
role of many physicians and health scientists was mixed with other work in epidemiology, public health, preventive medicine, public health policy, screening, and occupational health law throughout the Nazi era. ${ }^{15,16}$ While Nazi Germany was rampaging throughout Europe perpetrating mass slaughter, some health professionals were working on innovative health and prevention interventions promoting life. At the same time many of their colleagues were working on destroying life. Psychiatrists deceived their patients and patients` families. Physicians were complicit in forcing their patients to be sterilized, arranged their deaths, used them as test subjects for research, performed "involuntary euthanasia" and participated in the Final Solution. ${ }^{17}$ The question remains unanswered: how could such an enormous criminal conspiracy and shift in cultural values occur among highly educated and trained physicians in a "society" who were well aware of Aristotelian Ethics and the Hippocratic Oath, and how can such a tragedy be avoided in the future?

In order to better understand what occurred, we aim to review the history of devolution from humiliation and classification of mental patients, other ill and disabled individuals and different ethnic groups, leading to their exclusion, sterilization, and finally to "involuntary euthanasia" (a euphemism for medical murder); discuss the ethical norms of universal dignity, compassion and responsibility; and propose concrete steps of action for preventing medical rationalizations that promotes the participation of the psychiatric and public health community in crimes of mass atrocity or other assaults on humans and human moral values. ${ }^{15}$

\section{THE IDEAL OF RACIAL AND GENETIC PURITY AND STAGES OF HUMILIATION, EXCLUSION, AND EXTERMINATION}

The fantasy of an "ideal" society with "ideal" individuals, the paradigm of eugenics was a movement in many countries in the late $19^{\text {th }}$ and early $20^{\text {th }}$ century, ${ }^{21}$ primarily influenced by scientific developments such as Darwinism and the Mendelian and Lamarckian theories of heredity. The origins of eugenics can be traced back to classical times, to the Spartans, who appear to have been among the first to systematically regulate marriages and to kill the mentally ill, the diseased and the disabled. Modern Eugenicists sought control over the range of physical and mental characteristics they deemed acceptable for people ${ }^{22,23}$ in order to create societies free of individuals considered to have undesirable hereditary characteristics, and to keep these persons from reproducing. ${ }^{15,24}$ Consequently, sterilization of mentally ill patients was seen as a way of "social engineering". ${ }^{25,26}$ Sterilization was 
performed in many countries, among others it occurred in the United States, Sweden, Canada, Norway, Finland, Denmark, Estonia, Switzerland and Germany, ${ }^{15,27,28}$ and continued in Scandinavia until the 1970s. ${ }^{2}$

In Germany, the ideal of purity and supremacy of the "German Volk" was a guiding principle of Nazi ideology. ${ }^{30}$ The medical profession participated from the beginning of the regime in the planning and implementation of humiliation and classification, separation and exclusion, and thereafter in forced sterilization and murdering, by starvation, poisoning and gassing, of disabled and sick children and adults (termed "involuntary euthanasia"). The gassing techniques developed in what was known as the "T 4 Program" administered from Adolf Hitler's headquarters were later transferred along with the experienced personnel to the industrialized use of gassing in the concentration camps for genocidal mass murder. ${ }^{31-33}$

\section{Stage one: Forced sterilization of mentally ill and disabled (1933-1945)}

In 1933, a few months after seizing power, the Nazis mandated a series of eugenics measures: they prohibited the sale of contraceptives; emphasized the role of women as mothers, and limited working opportunities for women. Also in 1933, two laws were passed: the Law for the Restoration of the Professional Civil Service (April $6^{\text {th }}$ ) which excluded those defined by hereditary traits (especially Jews) from government jobs, and the Law for the Prevention of Progeny with Hereditary Diseases (Gesetz zur Verhütung erbkranken Nachwuchses $(\mathrm{GVeN}))$ (July 14 $\left.{ }^{\text {th }}\right)$ which separated, classified and excluded those with hereditary diseases to "protect future generations" ${ }^{34}$ and to improve the "German race". ${ }^{35} \mathrm{GVeN}$ legalized the forced operative sterilization of individuals with "congenital diseases" 36,37 (i.e., congenital feeblemindedness, schizophrenia, hereditary epilepsy, manic-depressive psychosis, severe alcoholism, hereditary deafness, hereditary blindness, severe malformations, and Huntington`s chorea). ${ }^{38}$ The impact of GVeN was immediate with an estimated 388,400 forced sterilizations (35\% reported by directors, $21 \%$ by physicians of the Public Health Service, $20 \%$ by other physicians, $20 \%$ from other sources). ${ }^{4}$ The individuals sterilized were diagnosed as follows: congenital feeblemindedness: 52.9\%; schizophrenia: $25.4 \%$; hereditary epilepsy: $14.0 \%$, manic-depressive psychosis: $3.2 \%$; severe alcoholism: $2.4 \%$; hereditary deafness: $1.0 \%$; hereditary blindness: $0.6 \%$; severe malformations: $0.3 \%$; and Huntington`s chorea: $0.2 \%{ }^{38} \mathrm{GVeN}$ was later expanded to include "dangerous habitual criminals" and allowed for the involuntary abortion of a fetus during the first six months of pregnancy carried by a mother with "hereditary illness". $6,7,15$ 
In 1935, the Marriage Health Law (July $14^{\text {th }}$ ) mandated screening of the entire population in Germany to prevent marriages of persons considered carriers of hereditary degeneracy. The psychiatrist and director of the Kaiser Wilhelm Institute (KWS) for Psychiatry in Munich, Ernst Rüdin (President of the Association of German Neurologists and Psychiatrists, 1933-1945), was involved in writing the official commentary to the law as President of the German Research Institute of Psychiatry. ${ }^{14,35}$

There were carefully thought out criteria, protocols and procedures for sterilization. All medical doctors in Germany were obliged to report "hereditarily diseased" individuals to the authorities in Berlin. Hereditary Health Courts (composed of a judge and two health officers) were set up in which a jury of "experts" determined who should be sterilized. ${ }^{15,39,40}$ Men underwent vasectomy and women underwent tubal ligation or exposure to radiation. ${ }^{5}$ The law resulted in the sterilization of an estimated 300,000 400,000 individuals. ${ }^{37}$

Stage two: "Euthanasia" of the mentally ill, disabled children and juveniles (1939-1945)

As far back as 1920, during the Weimar Republic, the Professor of Psychiatry Alfred Hoche published "Allowing the Destruction of Life Unworthy of Living" in collaboration with the Professor of Law Karl Binding. ${ }^{41}$ In 1939 the German Reich Ministry of Interior ordered midwives and physicians to report at childbirth the family history, hereditary diseases, family alcohol or substance use, and infants born with such conditions as hydrocephaly, missing limbs or bifida of the head and spinal cord, and paralyses.$^{42}$ The reports had to be sent to Berlin where the fate of the child was decided by a panel of medical doctors: Professor Werner Catel a psychiatrist from Leipzig, Professor Hans Heinze, head of an institution for children with intellectual disabilities, Dr. Ernst Wentzler, a psychiatrist and Dr. Helmut Unger, of whom three were required to give their approval before a child could be killed. ${ }^{9}$ Based on the reports, disabled children from all over Germany were sent to specially arranged "euthanasia" units. In these units, physicians and nurses killed the infants with injections of morphine, high doses of the sedative phenobarbital (Luminal) or the sleeping pill barbital (Veronal), or by systematic starvation. ${ }^{43}$ The Reich Committee for the Scientific Registry of Hereditary and Congenital Illnesses established at least 22 killing wards for children. The brains of the murdered children were often sent by professionals working in these facilities to research institutions, notably the world famous Kaiser Wilhelm Institute for Brain Research in Berlin. ${ }^{44}$ 
Stage three: "Euthanasia" of adults in Germany and in the countries under Nazi rule (1939-1941)

Stage three targeted adults. It began on September $22^{\text {nd }}, 1939$ with the shooting of Polish disabled persons, when SS Major Kurt Eimann, commander of an SS unit (Einsatzkommando) oversaw the shooting of approximately 2,000 patients of the Kocborowo (Conradstein) mental institution, south of Danzig, and of approximately 1,400 individuals with disabilities from the institution for disabled in Pasnitz, near Neustadt. The Chancellery of the Führer oversaw the administration and coordination of what came to be known as the "T 4 Program" (Aktion T 4), because it was physically based at Tiergartenstrasse 4 Hitler's headquarters.

Hitler issued the so-called "Euthanasia Decree" (later called the "T 4 Decree") backdated to the first of September 1939 (the day of the invasion of Poland and the beginning of World War II). The Decree authorized Philipp Bouhler, the head of the Chancellery of the Führer, and his personal physician ${ }^{45,46}$ Dr. Karl Brandt, to authorize designated doctors to carry out "mercy killing" with the following words: “... that those suffering from an incurable disease can be granted a merciful death." ${ }^{47}$ This sentence is an example of the skillful manipulation of language which inverted words to mean the opposite as euphemisms to disguise the actual reality, so as to cover up the program, and thus allowed many people to willingly support the criminal activities of the T 4 Program perfected by the Nazi propaganda machine. Psychiatrist Professor Werner Heyde, Chair of Psychiatry and Neurology from Würzburg University and Captain (Hauptsturmführer) in the SS, was appointed Medical Director of the T 4 Program and in 1944 was awarded the SS Honour Ring (Skull ring). ${ }^{48}$ But not everyone was deceived. During 1940 rumors of what was taking place spread and many Germans withdrew their relatives from institutions to care for them at home, sometimes with the help of individual psychiatrists like Professor Hans Gerhard Creutzfeld who managed to save nearly all of his patients. ${ }^{9}$

The T 4 Program started after September 1939 when the war was launched and ended officially in 1941 because of protests from parents and church officials. Following the day of the Euthanasia Decree a single sheet order was sent to all psychiatric hospitals which had to be filled out by treating psychiatrists for their psychiatric patients. The sheet listed last name, first name, diagnosis, "race", ability to work and possible forensic history. The institutions were given a three to ten week period to return the lists to a central committee, which decided on whether to "euthanize" marking the sheets. In these sheets a red (+) represented "euthanasia" and a blue (-) represented survival. After the decision by the "chief expert", the 
Reich Working Group for Mental Asylums (RAG), one of four cover organizations for the T 4 Program, prepared a list of the sick to be transported to their death. Physicians determined the modes of death. ${ }^{9,50}$ In addition to "race" targeting Jewish, ${ }^{51}$ and Roma patients, ${ }^{52,53}$ selection criteria included the length of treatment and the classification as "untreatable", the assessment of behavior by caregivers and physicians, and an evaluation of what kind of work the patients could do (a category reflecting the crude utilitarian mindset of the organizers of the T 4 Program). At particular risk of being selected for "euthanasia" were persons viewed as chronically ill and those who were considered economically "unusable" for any productive work, as well as sick persons needing care and attention, with a clear gender-specific overrepresentation of female individuals. ${ }^{54}$

Drivers of specially adapted buses, called "grey buses" collected patients listed alphabetically for transfer to gas chambers in six mental institutions. ${ }^{55}$ The practice of gassing people was first developed in an old jail building, number 90c on Neuendorfer Strasse in the city of Brandenburg. Building of experimental gassing facilities were then constructed at a number of institutions. These included Grafeneck (January - December 1940), Sonnenstein-Brandenburg (from April 1940), Hartheim (from May 1940), Pirna-Sonnenstein (from April 1940), Bernburg and Hadamar (from January 1941). In these institutions, teams of physicians and nurses led the process; the patients were undressed and led to the gas chambers. ${ }^{56}$ The $\mathrm{T} 4$ operation lasted from January 1940 to August 1941..$^{12,57}$ The cadavers of those killed often became research objects, ${ }^{9,58}$ presenting unprecedented opportunities for unscrupulous and ambitious researchers. ${ }^{62}$

Public protests did not come from the medical profession but from churches (e.g., from Theophil Wurm, the protestant Bishop of Württemberg; Pastor Paul Gerhard Baune; Pastor Friedrich von Bodelschwingh; Cardinal Adolf Bertram; Cardinal Michael Faulhaber, and Count Clemens August von Galen, Bishop of Münster) and from some parents of "disappeared" children. These protests and probably the emptying of institutions led to the official closing of the T 4 Program on $24^{\text {th }}$ August $1941 .{ }^{49}$ By this time approximately 400,000 psychiatric and/or patients with disabilities were murdered..$^{59,60}$ Now the Nazis felt ready for their next move and applied the know-how and experience from the T 4 operation to develop Operation Reinhardt and the Final Solution, following the Wannsee Conference on January $20^{\text {th }}, 1942 .{ }^{.61}$ 
Stage four: Uncoordinated "euthanasia", murder of Jews and of prisoners of war in mental hospitals, Operation Reinhardt and the Final Solution (1941-1945)

Medical personnel continued to carry out killing of children and adults, even after 1941 when Hitler had officially stopped the centrally organized Aktion T $4 .{ }^{4}$ In this decentralized stage of what has been termed "wild euthanasia", large numbers of patients were killed (the exact number still is not known) by overdoses of medicine or planned starvation. ${ }^{62}$

One example was the Bavarian state hospital at the city of Kaufbeuren, which served as a transfer institution prior to the official end of the T 4 Program and later as a center for "wild euthanasia" (including a children's killing ward). The staff personnel at Kaufbeuren continued to carry out patient killings following Germany's surrender in May 1945, when US troops occupied Kaufbeuren, until July $2^{\text {nd }}$ when Germany's unconditional surrender became official. On that day, more than 60 days after the US military had entered the city, soldiers accessed the hospital and discovered, to their horror, a still functioning extermination institution., ${ }^{4,63}$

In 1941, concentration camp inmates were murdered by medical personnel in psychiatric hospitals in an operation called "Action 14f-13". " $14 \mathrm{f}$ " was the code term used by concentration camp officials to indicate the death of an inmate, and " 13 " the term for the transfer to a $\mathrm{T} 4$ facility. The murder of disabled Jewish patients began almost a year before the Final Solution.

Finally, the Nazis held the Wannsee Conference on January 20 ${ }^{\text {th }}, 1942$, and ratified carefully organized mass extermination of world Jewry as official policy, and called it "The Final Solution of the European Jewish Question" (Endlösung der europäischen Judenfrage). At this conference, the planners set out the objectives, methods, organization and work plans to carry out the industrialized mass extermination of Jews and Roma (Gypsies) termed "Operation Reinhardt". 9,15,64 The Nazis began work in March 1942 building the three Operation Reinhardt extermination camps, Belzec, Sobibor and Treblinka, for the mass killing of Jews and Roma. It ended in October $1943 .{ }^{4}$ Operation Reinhardt grew out of T 4 . Almost all personnel of Operation Reinhardt were drawn from the $\mathrm{T} 4$ organization. ${ }^{3}$ The Nazis used Auschwitz-Birkenau and Chelmo as further extermination camps and many hundreds of smaller camps as labor and concentration camps where death by brutality and starvation were common for inmates-Jews, homosexuals, Roma, political prisoners and many others. Unethical experimentation on humans and other atrocities at the concentration camps under direction of medical doctors had started with humiliation of people 
classified as inferior, by a policy of excluding them from the human race as a justification for forced sterilization and "euthanasia". These procedures escalated methodically into industrialized mass killings. The legitimizing cover for these crimes that had been furnished by Professor of Psychiatry, Alfred Hoche and Professor of Law, Karl Binding advocating the "destruction of life unworthy of living" by pseudo-science and pseudo law had been fulfilled. This betrayal of their vocations by these men and by innumerable others was clearly in breach of medical and legal ethics of the time. The mass murder, however, exceed the range of language available for judgment, outrage or condemnation. The focus of our inquiry in this article is not the Holocaust and mass murders as such, but the betrayal of their mission as doctors and the unethical behavior of individuals in the Medical profession, especially of psychiatry, during the Nazi period in Germany and its conquered nations.

\section{DISCUSSION}

Robert Jay Lifton in his famous book "The Nazi Doctors: Medical Killing and the Psychology of Genocide" defined the euthanasia sanctioned by physicians as "medicalized killing". ${ }^{65}$ Their actions were in direct violation of long-established medical ethical standards such as the Hippocratic Oath (e.g., First, do no harm) and the Ethics Code established February $28^{\text {th }} 1931$ in Nuremberg ("Regulations on New Therapy and Human Experimentation"), (e.g., responsibility for the well-being of the patient, and informed consent). The historical documents show that the vast majority of physicians not only did not resist but actively participated in acts of humiliation, exclusion, segregation and extermination. There could be many explanations: enthusiasm for Nazi ideology of racial and genetic purity with superior and inferior races (Übermenschen and Untermenschen); contempt for the right of the individual who was being sacrificed for the greater good of the state, and total lack of compassion for the victims. But above and beyond all these explanations, there is a simple one: plain greed.

The centrality of "euthanasia" and the Final Solution in the Nazi party program created almost irresistible opportunities for an individual's career development. Jobs in the business of "euthanasia" and in the Final Solution provided potential access to influence, power, and prestige. ${ }^{66}$ Psychiatry was a promising field in the 1930 s with new therapy methods (e.g., open care according to the Erlangen model, insulin shock therapy). Mental clinics were crowded with chronic patients. Young doctors, who were the most innovative and enthusiastic, working with the new therapies, may 
have been easily convinced to accept and participate or excuse the killing of the non-curable ill and destruction as an inevitable professional part of healing the curable. ${ }^{67,68}$ In this process, the sacrifice of the individual became part of the social norm ideal of "constructing an ideal society" and of "healing the society". While inhuman and morally unacceptable, this is often construed as some "explanation" for the programs, but it does nothing to alleviate the shameful breach of medical ethics, when physicians did not object to and often participated in the humiliation of those who were to be killed (Table 1).

The sad, historical fact is that the medical profession was one of the highest professions to join the Nazi Party and accept the propaganda of the regime or its laws and decrees, by which human beings were deemed unworthy of life and unworthy of protection. Destruction of the individual became professionally and socially accepted as an inevitable part of a perverse ideal of "healing the society". During the post-war Trials of the Major War Criminals before the International Military Tribunal in Nuremberg, Germany (November 20 $0^{\text {th }}, 1945$ - October $1^{\text {st }}, 1946$ ) the "therapeutic idealism" was clearly recognized as an unethical aberration and constituted Crimes against Humanity. One item to note was that women were selected for execution more often than men suggesting the need to investigate further the gender aspect in the "euthanasia" debate. ${ }^{69}$

We record that some heroic medical doctors (e.g., Alexander Mitscherlich, Haakon Saethre, Walther Spielmeyer, Jules Tinel, Johannes Pompe, Max Nonne, Karl Bonhoeffer, and Oswald Bumke), and medical students, stood up to the Nazi regime. Among them were five medical students who participated in the White Rose resistance group. ${ }^{50}$ Such resistance was isolated in Germany, but occurred more in the occupied countries. Dutch physicians jointly resisted the efforts by the occupying German Army to select the sick ${ }^{56}$ and turned in their medical licenses, but continued to see their patients privately. ${ }^{50}$ 


\section{Table 1}

Dates, laws and decrees, events, camps and killings sites and approximate number of individuals killed by euthanasia, 1933-1945

\begin{tabular}{ccc}
\hline Date $\quad$ Laws, Decrees, Events, Camps, Killing Sites & $\begin{array}{c}\text { Appr. No. of } \\
\text { Victims }\end{array}$ \\
\hline
\end{tabular}

1933, Mar. 20 SS opens the Dachau concentration camp as prison for political opponents.

1933, April 1 Boycott of Jewish owned shops and businesses.

1933, April 7 Law for the Re-establishment of the Professional Civil Service

1933, July 14 Law for the Prevention of Progeny with Hereditary Diseases

1933, Sept. 29 Hereditary Farm Law

1934, Nov. Law Against Dangerous Career Criminals

1934, Dec. 10 SS chief Himmler creates the Inspectorate of Concentration Camps.

1935, June Law for the Alteration of the Law for the Prevention of Appr. 400,000 were Hereditarily Diseased Offspring

1935, Sept. 15 Law for the Protection of German Blood and German Honor; Citizenship Law

1935, Oct. Law for the Protection of the Hereditary Health of the German People

1935, Nov. 15 Citizenship Law (Reichsbürgergesetz) - distinguished citizens (Aryan Germans) from inhabitants (unmarried women, non-Aryans) and deprived Jews of their civil rights.

1936, June 6 The Racial Hygiene and Population Biology Research Unit of the Ministry of Health is established. This office interviewed, measured, studies, photographed, fingerprinted and examined Roma (Gypsies).

1936, July 12 SS opens Sachsen-hausen concentration camp.

1937, July 15 SS opens Buchenwald concentration camp.

1937, Dec.14 Decree on Preventive Suppression of Crime by the Police

In the "Reichs Medizinal Kalender" (directory of doctors) Jewish doctors remaining in Germany were stigmatized by a colon placed before their names. 
1938

1938, Nov.

9-10

1938

1938

1938, June

13-18

1938

1938, July 25 The government withdraws the licenses of all Jewish physicians. They were degraded to "providers" (Behandler).

1939, Sept. 1 World War II

Dated 1939, Euthanasia Decree

Sept. 1

Polish Jews must relocate. They are required to wear armbands or yellow stars.

Establishment of 356 ghettos in Poland.

1939, Winter - "Euthanasia" in Brandenburg on the Havel. 1940, Sept.

Auschwitz-Birkenau in operation.

1940, Jan. - "Euthanasia" in Grafeneck in Württemberg

Dec.

1940, May - "Euthanasia" in Hartheim, Austria. 1944, Dec.

1940, June - "Euthanasia" in Sonnenstein, Pirna 1943

1940, Sept. - " "Euthanasia" in Bernburg on the Saale 1943

Law makes it illegal to change one`s first or last name. All Jewish organizations required to register with government authorities. Ordinance designates 316 names as officially "Jewish"; Jews with other names required to add "Israel" or "Sarah" to their names. Jews and their spouses required to register all their property with the authorities. Jews required to apply for special papers identifying them as Jewish.

November $15^{\text {th }}$ Jews barred from attending German schools.

Aprox. 30,000 Jewish men imprisoned in Dachau, Sachsen-hausen and Buchen-wald.

Decree on the Elimination of the Jews from Economic

emprisoning appr. 10,000 men as "asocials" including 2,300 Jews

SS opens concentration camp in Mauthausen. 
1940, Dec. "Euthanasia" in Hadamar

Appr. 10,072

-1941, Aug.

The Operation Reinhardt extermination camps of Appr. 1,526,000 Belzec, Majdanek, Sobibor, Treblinka II, Belzec begin operation.

1941, March 1 Construction of the extermination camp in AuschwitzBirkenau, Poland.

1941, June Mobile killing units begin the systematic killing of Jews. Massacre of Jews and Roma at Babi Yar, Ukraine.

1941, July 6 Shooting of Jews in Kovno. Appr. 3,000

1941, July Murder of Jews in Iasi, Romania.

1941, July 17 Appointments of three Higher SS leaders to coordinate and expand mass killing operations.

1941, Aug. 3 Bishop Graf von Galen denounces the "euthanasia" killing program in a public sermon.

1941, Aug. 24 Hitler orders the cessation of centrally coordinated "euthanasia" killings.

Einsatztruppen shoot Jews near Kiew, Ukraine.

Einsatztruppen shoot Jews in the Minsk Ghetto.

1941, Dec. 8 First killing operations begin in Chelmo, Poland.

1942, Jan. 20 Wannsee Conference with the Final Solution plan.

1942 - $1944 \quad$ Hundreds of subcamps established.

\begin{tabular}{ll}
\hline & Events specifically related to the Romani People \\
\hline 1940, Spring & $\begin{array}{l}\text { Deportation of Roma from the Reich to the } \\
\text { Generalgouvernement (German occupied Poland). }\end{array}$ \\
1941 & 5,000 Austrian Roma deported to the Lodz Ghetto. \\
1941 , Dec. & Einstztruppen shoot 800 Roma in Simferopol (Crimea). \\
1941, Dec. 16 & $\begin{array}{l}\text { Himmler gives the order for all German Roma to be } \\
\text { sent to Auschwitz. }\end{array}$ \\
1943 & $\begin{array}{l}\text { Family camp for Roma constructed in Auschwitz- } \\
\text { Birkenau. }\end{array}$ \\
1942 - 1944 & $\begin{array}{l}\text { Hitler orders all Dutch Roma to be sent to Auschwitz. } \\
\text { Night of the Gypsies (Zigeunernacht): All Roma who } \\
\text { remained in Auschwitz were gassed. }\end{array}$
\end{tabular}

$\begin{array}{ll}\text { Killed by "euthanasia" } & \text { Appr. 300,000- } \\ & \mathbf{4 0 0 , 0 0 0}\end{array}$

Sources: Evans (2008), ${ }^{13}$ Süss (2003), ${ }^{59}$ Zeidman (2011), ${ }^{66}$ Siemen (1987), ${ }^{67}$ Kersting and Schmuhl $(2004)^{68}$ 


\section{RECOMMENDATIONS}

In 1949, Dr. Leo Alexander, the American psychiatrist who played an important role in the Nuremberg trial by writing parts of the Nuremberg Code of 1947, noted that in the Nazi state, atrocities started from small beginnings which became "norms". The increasingly popular acceptance of Nazi state policy allowed physicians to justify, accept and become part of horrendous violations of human rights beginning with the forced sterilization of men and women, to the murder of severely disabled children, to the killing of older children with fewer and fewer disabilities, and finally, to kill those who were ideologically considered unsuitable for life. ${ }^{8,70}$ It yet remains to be seen whether this frightening, seemingly logical progression of medical participation in rationalized mass killings of humans in the $20^{\text {th }}$ century will serve as a sufficient warning to prevent similar atrocities in the $21^{\text {st }}$ century and beyond.

It is no doubt true that several examples exist of incomprehensible large-scale ethnic or politically based killings since the Nazi era. Many consider these killings to be on a similar level of genocide to what transpired during the Nazi period and include the millions displaced and/or killed in Cambodia in the 1970s, in Rwanda during the 1990s and Sudan in the 2000s. Thus it appears that genocide does still continue all over this planet, starting with hate speech, building to dehumanizing the "other", followed by an acceptance of systematic killing. But these were not led and implemented by doctors, and we focus in this paper on the role of medicine and its practitioners and how the field became implicated in one such serious genocide of monumental proportion and how medical and public health ethics need to act to prevent such egregious atrocities in the future.

Substantive, important principles relating to ethics have been published in many declarations following the Nuremberg Code of 1947 including beneficence and non-maleficence, autonomy, informed consent, protection of persons unable to consent, privacy and confidentiality. ${ }^{71}$ We would like to emphasize the need for human rights legislation to ensure their protection in the medical field..$^{72}$ The Universal Declaration on Bioethics and Human Rights was an important step in the search for bioethical standards. ${ }^{71}$ Besides these important principles and the umbrella of human rights laws to ensure their protection, we emphasize in this article the principles of respect for the sanctity of human life, universal human dignity, compassion and relationships, responsibility and courage. 


\section{Respect for universal human dignity}

The idea of dignity has a long historical and philosophical tradition and has been particularly salient in medical ethics and bioethics, perhaps beginning with the Ten Commandments and the biblical ${ }^{73}$ The concept of dignity plays a key role in ethics. However, it includes several meanings. In the $20^{\text {th }}$ century it is found in a variety of documents: in the German Constitution drawn up in 1919 by the Weimar National Assembly, even in the corporate fascist Portuguese Constitution of 1933, in the 1945 Charter of the United Nations, and in the Universal Declaration of Human Rights of $1948 .^{71}$

The concept of dignity is based on the biblical precept of the sanctity of human life. The idea of dignity is a difficult concept and has a potentially dangerous side. Different characteristics of what is understood as "dignity" have been suggested: dignity of merit, dignity of moral stature, dignity of identity and the universal human dignity (Menschenwürde). ${ }^{75}$ Dignity as a merit is defined by one's social rank and position and can be understood in terms of the Aristotelian ideas of excellence and virtue. In this concept dignity can be cultivated, fostered and promoted. The dignity of moral stature pertains to moral deeds of the subject and can be reduced or lost through immoral behavior. Dignity of identity pertains to the integrity of the subject's body and mind. This dignity can come and go as a result of the actions and opinions of others. Universal human dignity (Menschenwürde) is intrinsically linked to human beings and is above any desires for "social engineering".

If we start to identify human beings according to their features, perceived value and their economic and societal usefulness, there is no limit. When governmental or religious official propaganda and norms dehumanize groups and/or individuals, defining them as "heretics" or "unworthy of living" and eventually by using medical terms to describe individuals as a disease (e.g., "virus" or "cancer"), or as descendants of animals (e.g., "monkeys" or "pigs") this is meant to and can easily cause listeners to feel revulsion towards the groups so described and who can then be victimized. The general public and physicians were readily seduced by such propaganda in Nazi Germany to involve many thousands of willing and active perpetrators, and occurring in other instances since.

It cannot be stressed enough that universal human dignity is a cornerstone of basic ethics and morals. Universal human dignity as an ethical value requires compassion and relationships. The examples we present from the Nazi era show that the concept of dignity without compassion and relationships can lead to exclusion and gradation of human lives and eventually to mass-murder, euphemistically termed "euthanasia". 


\section{Compassion and relationships}

Relationships, built on respect and compassion between the physician and the patient is central to the Hippocratic tradition. ${ }^{15}$ Compassion is the feeling and understanding of the suffering of others. This value of compassion and relating to others is apparently compromised in any action which ignores the rights of the individual in order to "improve" the population, for racial, economic, political or "scientific" reasons. The lack of compassion for individual persons as a social norm may be the fundamental reason why psychiatrists in Germany failed their professional oath and their responsibility to protect their patients. But physicians of the Nazi era did invoke compassion to justify "euthanasia". This notion of "compassion" as a way of rationalization of "euthanasia" occurs today as well. In a paper published only a year ago, the authors argued for the termination of life of a child born either with disabilities, or an unwanted child, in what they termed "after-birth abortion", ${ }^{76}$ but this is not accepted practice.

The value of compassion and relationships is under constant pressure and may need strengthening by human rights legislation and by emphasizing the values of responsibility and courage.

\section{Responsibility and courage}

Public health physicians and other professionals have a "population perspective" of Public Health in terms of health protection and health promotion. This may lead to contradictions between individual universal human dignity, the individual relationship with the patient, and the common good of the community in a utilitarian perspective. These contradictions need to be considered on a case-by-case method of ethical analysis, with responsibility as a leading value and courage as the attitude. Examples abound, in restriction of smoking in public places or driving on the wrong side of the road or being inebriated while driving, thus putting other at risk.

Responsibility is thought to have several components, personal responsibility, moral responsibility, and substantive responsibility. Personal responsibility is taking responsibility for past actions done, without trying to avoid the consequences. In Nazi Germany the leading psychiatrists of the time, administrators, nursing and other staff voluntarily and often enthusiastically took part in all stages of the operation to kill their defenseless victims. But many of these medical perpetrators of mass murder and many German bystanders, when confronted after the war with their deeds, denied any knowledge or responsibility. They mostly referred to their status as lawful public servants, obliged to obey their superiors and to the "Führer" 
himself. The behavior of these psychiatrists failed to show courage, by removing responsibility from themselves and claiming that their duty was only to obey. This gambit was used by many perpetrators and bystanders after 1945 to explain their deeds. The giving up of individual responsibility might be an important step towards obedience..$^{56}$ In this context, obedience was a negative trait, used to excuse their failure to live up to the value of courage.

Courage can be defined as the willingness to face difficulties such as physical danger, emotional pain, disapproval, joblessness, financial insecurity or even death, rather than compromise on values which are deemed more important, or uncompromisable. Courage has been investigated from different perspectives since ancient times. ${ }^{79}$ In this tradition, courage is an action based on core values, awareness of risks, readiness to endure danger and willingness to endure hardship for the sake of principle, courage with virtuous convictions as compassion and responsibility is the bridge between talking ethics and doing ethics. ${ }^{80}$

\section{CONCLUSION}

The purpose of this paper was to investigate the breach of ethical norms by the medical establishment in Germany during the Nazi period, by reviewing the different stages of humiliation, exclusion, sterilization, "euthanasia" and genocide committed in Nazi dominated Germany and the involvement of medical personnel in these acts. Racial hatred based on an ideology of placing the racial purity of the population above individual life and basic human rights, were the driving forces, as well as individual career aspirations.

The example of the ethical failure of Nazi psychiatry is a prime illustration of how ethics codes and ethical teachings may come to be ignored when the dominant culture of a nation shifts to radically racist and unethical norms of individual, collective and professional values. We hope that a deeper understanding of how psychiatry was co-opted during the Nazi period can contribute to the strengthening of medical ethics. Public mental health cannot afford to turn a blind eye on such a past. We need to build on the values of individual life and dignity, compassion and relationships, responsibility and courage, in general and in medical education. The acceptance of universal ethical norms of human dignity and human rights are the cornerstones. Therefore, we need to remember, to acknowledge and to value the dignity of the victims by: 


\section{Memorialization and active engagement with the past}

- We must demonstrate to and educate current and future generations about the evidence of medical participation in Germany's Nazi past and continue to investigate and document the details of what has occurred.

- We must continue to investigate and document the lives of the perpetrators and the millions of individual victims.

- We must record the medical doctors and institutions involved in the practice of sterilization, and "euthanasia" of patients and their careers after 1945.

- We must honor those physicians who resisted the pressures of the Nazi regime and stood up in protection of basic human rights-as positive role models; and those who were victims of the Nazi sterilization, "euthanasia" and genocide.

- We must dishonor those involved in sterilization and "euthanasia" as negative role models. For example, as suggested by Strous and Edelman, eponyms by doctors who exhibited unethical behavior and complicity during the Nazi period for personal professional gain should be reviewed, and alternative names should be recommended. ${ }^{18}$

\section{Education}

- We must promote the understanding of the young about the dangers of racial incitement and the need for compassion and human rights and relationships by means of interdisciplinary research and educational programs.

- We need revisiting of ethical breaches in conduct by those in the medical profession who have erred in the past. Revisiting these breaches of ethical conduct in the context of a healthy historical learning experience by students across the range of the health care professions will go a long way in order to address this issue. This arguably is an even more important and useful learning experience than simply studying ethical concepts in the absence of historical context

- By integrating education, science and arts we should attempt to design and set up courses in medical ethics, and insist that all medical students are given an understanding of the need to embrace ethical values of individual life and human dignity as their own.

\section{Communication}

- Multinational communication to jointly confront the past of perpetrators, bystanders and victims. 
Finally, we acknowledge the difficult process of writing this article, as a joint multidisciplinary article written by scientists from Germany, Israel, Finland and the United States. We hope that this joint project of investigating the past and disclosing the past together may be one more important step towards prevention.

\section{Appendix 1}

Names, position and role of physicians involved in "euthanasia"

\begin{tabular}{|c|c|c|}
\hline Name & Position & Role \\
\hline Eugen Fischer & Chair in Anthropology, Berlin & Advocate of racial research \\
\hline $\begin{array}{l}\text { Hans F. K. } \\
\text { Guenther }\end{array}$ & $\begin{array}{l}\text { Chair in Anthropology, Jena, } \\
\text { Berlin, Freiburg }\end{array}$ & Advocate of racial research \\
\hline Alfred Hoche & Chair in Psychiatry, Freiburg & Advocate of "euthanasia" \\
\hline Ernst Ruedin & $\begin{array}{l}\text { Director, KWI Psychiatry, } \\
\text { Munich }\end{array}$ & $\begin{array}{l}\text { Advocate of racial research and } \\
\text { "euthanasia" }\end{array}$ \\
\hline Werner Catel & Chair in Pediatrics, Leipzig & $\begin{array}{l}\text { Medical expert for children's } \\
\text { "euthanasia" }\end{array}$ \\
\hline Max de Crinis & Chair in Psychiatry, Cologne & Medical expert for adults "euthanasia" \\
\hline $\begin{array}{l}\text { Julius } \\
\text { Hallervorden }\end{array}$ & Brain research & Brain research on "euthanasia" victims \\
\hline Werner Heyde & Chair in Psychiatry, Wurzburg & T4 Medical director \\
\hline Berthold Kihn & Chair in Psychiatry, Jena & Medical expert for adults "euthanasia" \\
\hline Friedrich Mauz & Chair in Psychiatry, Konigsberg & Medical expert for adults "euthanasia" \\
\hline Friedrich Panse & Professor of Psychiatry, Bonn & Medical expert for adults "euthanasia" \\
\hline Kurt Pohlisch & Chair in Psychiatry, Bonn & Medical expert for adults "euthanasia" \\
\hline Carl Schneider & Chair in Psychiatry, Heidelberg & Director, T4 research center \\
\hline Werner Villinger & Chair in Psychiatry, Breslau & Medical expert for adults "euthanasia" \\
\hline $\begin{array}{l}\text { Viktor von } \\
\text { Weizsaecker }\end{array}$ & $\begin{array}{l}\text { Chair in Psychiatry-Neurology, } \\
\text { Breslau }\end{array}$ & Brain research on "euthanasia" victims \\
\hline Konrad Zucker & $\begin{array}{l}\text { Professor of Psychiatry, } \\
\text { Heidelberg }\end{array}$ & Brain research on "euthanasia" victims \\
\hline
\end{tabular}

Sources: Freelander (1995), ${ }^{4}$ Beyleveld and Brownsword (2001), ${ }^{73}$ Andorno (2009) ${ }^{74}$ A comprehensive list of neurologists involved was published recently by Gabriel and Wolfgang (2002). ${ }^{62}$ 


\section{Appendix 2}

"Euthanasia" centers, dates of functioning, and physicians involved, official number of victims

\begin{tabular}{|c|c|c|c|c|}
\hline Center & Dates & Physicians & Pseudonyms & $\begin{array}{l}\text { Official No. } \\
\text { of Victims }\end{array}$ \\
\hline \multirow{3}{*}{$\begin{array}{l}\text { Grafeneck in } \\
\text { Württemberg }\end{array}$} & \multirow{3}{*}{$\begin{array}{l}\text { Jan. to Dec. } \\
1940\end{array}$} & Dr. Horst Schumann & Dr. Keim & \multirow[t]{3}{*}{9,839} \\
\hline & & Dr. Ernst Baumhard & Dr. Jäger & \\
\hline & & Dr. Günther Hennecke & Dr. Ott (?) & \\
\hline \multirow[t]{3}{*}{$\begin{array}{l}\text { Brandenburg on } \\
\text { the Havel }\end{array}$} & \multirow{3}{*}{$\begin{array}{l}\text { Winter 1939- } \\
1940 \text { to Sept. } \\
1940\end{array}$} & Dr. Irmfried Eberl & $\begin{array}{l}\text { Dr. Schneider, } \\
\text { Dr. Meyer (?) }\end{array}$ & \multirow[t]{3}{*}{9,772} \\
\hline & & Dr. Heinrich Bunke & $\begin{array}{l}\text { Dr. Rieper, } \\
\text { Dr. Keller }\end{array}$ & \\
\hline & & Dr. Aquilin Ulrich & Dr. Schmitt & \\
\hline \multirow{2}{*}{$\begin{array}{l}\text { Hartheim near } \\
\text { Linz }\end{array}$} & \multirow{2}{*}{$\begin{array}{l}\text { May } 1940 \text { to } \\
\text { Dec. } 1944\end{array}$} & Dr. Rudolf Lonauer & Not known & \multirow[t]{2}{*}{18,269} \\
\hline & & Dr. Georg Renno & Not known & \\
\hline \multirow{5}{*}{$\begin{array}{l}\text { Sonnenstein in } \\
\text { Pirna in Saxony }\end{array}$} & \multirow{5}{*}{$\begin{array}{l}\text { June } 1940 \text { to } \\
1943\end{array}$} & Dr. Horst Schumann & Dr. Keim & \multirow[t]{5}{*}{13,720} \\
\hline & & Dr. Kurt Borm & Dr. Storm & \\
\hline & & Dr. Klaus Endruweit & Dr. Bader & \\
\hline & & Dr. Curt Schmalenbach & Dr. Blume (?) & \\
\hline & & Dr. Ewald Worthmann & Not known & \\
\hline \multirow{3}{*}{$\begin{array}{l}\text { Bernburg on the } \\
\text { Saale in the } \\
\text { Prussian } \\
\text { Province of } \\
\text { Saxony }\end{array}$} & \multirow[t]{3}{*}{$\begin{array}{l}\text { Sept. 1940- } \\
1943\end{array}$} & Dr. Irmfried Eberl & $\begin{array}{l}\text { Dr. Schneider, } \\
\text { Dr. Meyer (?) }\end{array}$ & \multirow[t]{3}{*}{8,601} \\
\hline & & Dr. Heinrich Bunke & $\begin{array}{l}\text { Dr. Rieper, } \\
\text { Dr. Keller }\end{array}$ & \\
\hline & & Dr. Kurt Borm & Dr. Storm & \\
\hline \multirow{4}{*}{$\begin{array}{l}\text { Hadamar in } \\
\text { Hessen }\end{array}$} & \multirow{4}{*}{$\begin{array}{l}\text { Dec. } 1940 \text { to } \\
\text { Aug. } 1941\end{array}$} & Dr. Ernst Buzamhard & Not known & \multirow[t]{4}{*}{10,072} \\
\hline & & Dr. Günther Hennecke & Dr. Ott (?) & \\
\hline & & Dr. Friedrich Berner & Dr. Barth & \\
\hline & & Dr. Hands- Bodo Gorgaß & Dr. Kramer & \\
\hline Total & & & & 70,273 \\
\hline
\end{tabular}

Source: Freelander $(1995)^{4(\mathrm{p} .103)}$ 
Acknowledgements: We would like to thank Professor Michael von Cranach for his contributions to this article.

Conflicts of Interest: None declared.

\section{About the Authors:}

Dr. Jutta Lindert is a professor of Public Health at the Protestant University of Ludwigsburg, Germany. She is visiting scientist at the University of Leipzig and at the Harvard School of Public Health. Her research focuses on the interplay of neurosciences, life events, culture and mental health and on the long-term health impact of violence on health and mental health. Dr. Lindert is President of the Section of Public Mental Health of the European Association of Public Health (EUPHA). As former head of a refugee camp she is dedicated to investigating discrimination and health inequalities and methods to overcome them. Before her career in Public Health, Dr. Lindert studied literature focusing on writing poems and literature on war and genocide.

Dr. Yael Stein is a physician and researcher at the Hebrew University-Hadassah medical center. She has researched the epidemiology and effects of various types of environmental and social exposures-including pesticides, electromagnetic radiation and hate language. She is a co-founder of the Jerusalem Center for Genocide Prevention. Dr. Stein is active in promoting pluralistic education, she is the former head of "Ganei Haim" Jewish pluralistic education association, and has participated in joint Israeli-Palestinian research projects.

Dr. Hans Guggenheim, a refugee from Nazi Berlin in England and in Guatemala during World War II, eventually settled in the United States. He studied Art history at the Institute of Fine Arts at New York University. From 1956 -1958, he traveled as an artist for LIFE magazine through Turkey, Iran, Afghanistan, Pakistan, India and Japan. Dr. Guggenheim's PhD dissertation in Anthropology was on National Self-Image formation in the Arts in a new nation, Trinidad and Tobago. He taught as visiting Associate Professor of Anthropology at MIT and Visiting Scholar at Harvard's Center for International Affairs where he did research for UNESCO. He was president of the Worldcrafts Federation for UNESCO and In 1976 he founded Project Guggenheim building art schools in Tibet, Guatemala, and many art programs in other countries around the world with the goal of providing opportunities for young artists and to encourage innovation as well as continuity for ancient art traditions. He has donated major works of Dogon art to the Israel Museum in Jerusalem, 36 prints of Goya's Disasters of War series to the National Museum in Vietnam, and other prints to PSU, Plymouth State University of New Hampshire. His book of sketches from Auschwitz (1987/2011) is being readied for publication.

Dr. Jouni J.K. Jaakkola is a Professor of Public Health and Director of the Center for Environmental and Respiratory Health Research at the University of Oulu. He has broad long-term interests in global health issues such as climate change, housing, air pollution, and water quality, as well as in history and philosophy of science. He is a former Chairman of the Ethics and Philosophy Committee of the International Society for Environmental Epidemiology. His professional mission is 
to conduct research on topics which help to solve emerging global public health problems. Dr. Jaakkola lives in Finland.

Dr. Rael D. Strous is an Associate Professor and Psychiatrist in the Department of Psychiatry at Sackler Faculty of Medicine in Tel Aviv, Israel. In addition, he is the Director of the Chronic Inpatient Unit at the Beer Yaakov Mental Health Center. While his research has primarily been in the field of biological psychiatry, he has also written several scholarly works on antisemitism, the Nazi era, ethics in psychiatry and the history of psychiatry and medicine.

\section{REFERENCES}

1. Bonhoeffer D. Letters and Papers from Prison. London: SCM Press; 1971.

2. Beck C. Sozialdarwinismus, Rassenhygiene, Zwangssterilisation und Vernichtung "lebensunwerten Lebens". Eine Bibliographie zum Umgang mit behinderten Menschen im "Dritten Reich" - und heute. Bonn: Psychiatrie Verlag 1995. [In German]

3. Burleigh M, (editor). Death and Deliverance: "Euthanasia" in Germany, 19001945. Cambridge: Cambridge University Press; 1994.

4. Friedlander H. The Origins of Nazi Genocide. From Euthanasia to the Final Solution. Chapel Hill, NC: University of North Carolina Press; 1995.

5. Klee E. "Euthanasie" im NS-Staat: Die "Vernichtung lebensunwerten Lebens". Frankfurt: Fischer Verlag; 1983. [In German]

6. Geiderman JM. Ethics seminars: physician complicity in the Holocaust: historical review and reflections on emergency medicine in the 21 st century, part I. Acad Emerg Med. 2002;9:223-31.

7. Geiderman JM. Ethics seminars: physician complicity in the Holocaust: historical review and reflections on emergency medicine in the 21st century, part II. Acad Emerg Med. 2002;9:232-40.

8. Alexander L. Medical science under dictatorship. New England J Med. 1949;241:39-47.

9. Lifton RJ. The Nazi Doctors: Medical Killing and the Psychology of Genocide. New York, NY: Basic Books; 1986.

10. Fischer BA. Maltreatment of people with serious mental illness in the early 20th century: a focus on Nazi Germany and eugenics in America. J Nerv Ment Dis. 2012;200:1096-100.

11. Schneider F. Psychiatry under National Socialism: remembrance and responsibility. Eur Arch Psychiatry Clin Neurosci. 2011;261:S111-8.

12. Von Cranach M, (editor). Psychiatrie im Nationalsozialismus. Munich: Oldenbourgh; 1999. [In German]

13. Evans RJ. The Third Reich at War. New York, NY: Penguin Group; 2008.

14. Nicosia FR, Huener J, (editors). Medicine and Medical Ethics in Nazi Germany. Origins, Practices, Legacies. Vermont: Berghahn books; 2002 
15. Cohen MM, Jr. Genetic drift. Overview of German, Nazi, and Holocaust medicine. Am J Med Genet A. 2010;152A:687-707.

16. Westermann S, Wiesing U. Von der Pravention bis zur "olympiareifen" Belegschaft--Konfliktlinien und Argumentationsfiguren zur Genetik in der Arbeitsmedizin in historischer Perspektive. [Genetic testing in occupational medicine--conflicts and arguments within a historical perspective]. Medizinhist J. 2011;46:51-82. [In German]

17. Rotzoll M, Hohendorf G. Krankenmord im Dienst des Fortschritts? Der Heidelberger Psychiater Carl Schneider als Gehirnforscher und "therapeutischer Idealist". [Murdering the sick in the name of progress? The Heidelberg psychiatrist Carl Schneider as a brain researcher and "therapeutic idealist"]. Nervenarzt. 2012;83:311-20. [In German]

18. Strous RD, Edelman MC. Eponyms and the Nazi era: time to remember and time for change. Isr Med Assoc J. 2007;9:207-14.

19. Strous RD. Psychiatric genocide: reflections and responsibilities. Schizophr Bull. 2010;36:208-10.

20. Von Cranach M. Ethics in psychiatry: the lessons we learn from Nazi psychiatry. Eur Arch Psychiatry Clin Neurosci. 2010;260:S152-6.

21. Bloch F. Medical scientists in the Nazi era. Lancet. 1986;1(8477):375.

22. Bauman Z. Modernity and the Holocaust. Cambridge: Polity Press; 1989.

23. Foucault M. The History of Sexuality. Vol. 1: An Introduction. London: Allen Lane; 1979.

24. Sofair AN, Kaldjian LC. Eugenic sterilization and a qualified Nazi analogy: the United States and Germany, 1930-1945. Ann Intern Med. 2000;132:312-9.

25. O'Mathuna DP. Human dignity in the Nazi era: implications for contemporary bioethics. BMC Med Ethics. 2006;7:E2.

26. Broberg G, Roll-Hansen N. Eugenics and the Welfare State: Sterilization Policy in Denmerk, Sweden, Norway and Finland. East Lansing, MI: Michigan State University Press; 1996.

27. Kevles DJ. The Name of Eugenics: Genetics and the Uses of Human Heredity. New York, NY: Knopf; 1985.

28. Baron JH. The BMJ's Nuremberg issue. Compulsory sterilisation of defective people was legal in several countries besides Germany. BMJ. 1997;314:440.

29. Braun K, Herrmann, SL, Brekke O. Zwischen Gesetz und Gerechtigkeit. Staatliche Sterilisationspolitiken und der Kampf der Opfer um Wiedergutmachung. Kritische Justiz. 2012;3. [In German]

30. Adams MB. The Wellborn Science: Eugenics in Germany, France, Brazil, and Russia. Oxford: Oxford University Press; 1990.

31. Longerich P. Politik der Vernichtung. Eine Gesamtdarstellung der nationalsozialistischen Judenverfolgung. Munich: Piper; 1998. [In German]

32. Broszat M. Hitler und die Genesis der "Endlösung". Vierteljahreshefte für Zeitgeschichte. 1977;25:739-75. [In German] 
33. Mommsen H. Die Realisierung des Utopischen: "Die Endlösung der Judenfrage im Dritten Reich”. Geschichte und Gesellschaft. 1983;9:381-420. [In German]

34. Gütt A, Rüdin R, Ruttke F. Gesetz zur Verhütung erbkranken Nachwuchses vom 14. Juni 1933 nebst Ausführungsverodrnungen. 2nd ed. Munich: J. F. Lehmanns; 1936. [In German]

35. Rölcke V, (editor). Wissenschaft im Dienst des Reiches: Ernst Rüdin und die Deustche Forschungsanstalt für Psychiatrie. Berlin: Metropol; 2008. [In German]

36. Herbst L. Das Nationalsozialistische Deutschland 1933-1945. Frankfurt: Suhrkamp Verlag KG; 1996. [In German]

37. Hansson N, Peters A, Tammiksaar E. Sterilisierungsoperateur und Forscher: Leben und Karriere Benno Ottows (1884-1975). [Sterilization surgeon and researcher: life and career of Benno Ottow (1884-1975)]. Medizinhist J. 2011;46:212-37. [In German]

38. Übersicht über die Durchführung zur Verhütung erbkranken Nachwuchses, R18/5585 (1934). [In German]

39. Ernst E. Commentary: The Third Reich--German physicians between resistance and participation. Int J Epidemiol. 2001;30:37-42.

40. Blecker J, Jachertz N, (editors). Medizin im Dritten Reich. Cologne: Ärzteverlag; 1989. [In German]

41. Binding K, Hoche A, (editors). Die Freigabe der Venichtung lebensunwerten Lebens. Ihr Mass und ihre Form. [Allowing the Destruction of Life Unworthy of Living. To What Extent and in What Form]. Leipzig: Meiner; 1920. [In German]

42. Hudson L. From small beginnings: the euthanasia of children with disabilities in Nazi Germany. J Paediatr Child Health. 2011;47:508-11.

43. Beddies T, (editor). Wenn Kinder “der Wissenschaft dienen”. Die Kinderklinik der Charité in der Zeit des Nationalsozialismus. Paderborn: Ferdinand Schöningh; 2008. [In German]

44. Rürup R, Schieder W, (editors). Die Kaiser-Wilhelm-Gesellschaft im Nationalsozialismus. Göttingen: Wallstein; 2000. [In German]

45. Rotzoll M, Hogendorff G, Fuchs P, et al., (editors). Die nationlsozialistische "Euthanasie"-Aktion "T4" und ihre Opfer. Paderborn: Schöningh; 2010. [In German]

46. Rotzoll M, Fuchs P, Richter P, Hohendorf G. Die nationalsozialistische "EuthanasieaktionT4":HistorischeForschung,individuelleLebensgeschichten und Erinnerungskultur. [Nazi action T4 euthanasia programme: historical research, individual life stories and the culture of remembrance]. Nervenarzt. 2010;81:1326-32. [In German]

47. Frewer A, Clemens E, (editors). Euthanasie und die aktuelle SterbehilfeDebatte. Die historischen Hintergründe medizinischer Ethik. ["Euthanasia" and the Current Debate on Assisted Suicide. The Historical Background to Medical Ethics]. Frankfurt: Campus; 2000. [In German] 
48. Blessing T, Wegener A, Koepsell H, Stolberg M. The Wurzburg Anatomical Institute and its supply of corpses (1933-1945). Ann Anat 2012;194:281-5.

49. Schmuhl HW, (editor). Rassenhygiene, Nationalsozialismus, Euthanasie: Von der Verhütung zur Vernichtunh "lebensunwerten Lebens", 1890-1945. Göttingen: Vandenhoeck \& Ruprecht; 1987. [In German]

50. Zeidman LA. Neuroscience in Nazi Europe part II: resistance against the third reich. Can J Neurol Sci. 2011;38:826-38.

51. Hühn M, (editor). Das Schicksal der jüdischen Patienten im Nationalsozialismus. Berlin: Edition Heinrich; 1988. [In German]

52. Hohmann J. Geschichte der Zigeunerverfolgung in Deutschland. 2nd edition. Frankfurt: Campus Verlag; 1988. [In German]

53. Hohmann JS. Robert Ritter und die Erben der Kriminalbiologie: "Zigeunerforschung" im Nationalsozialismus und in Westdeutschland im Zeichen des Rassissmus. Studien zur Tsiganologie und Folkloristik. Frankfurt: Peter Lang; 1991. [In German]

54. Goldhagen DJ. Hitler`s willing executioners. New York, NY: Alfred A. Knopf; 1996.

55. Strous RD. Nazi euthanasia of the mentally ill at Hadamar. American J Psychiat. 2006;163:27.

56. Von Cranach M. The killing of psychiatric patients in Nazi Germany between 1939-1945. Isr J Psychiatry. 2003;40:8-18; discussion 19-28.

57. Von Cranach H. [Euthanasia of mental patients in Germany during World War II]. Ann Med Psychol (Paris). 1985;143:352-60. [In French]

58. Müller-Hill B. Murderous Science: Elimination by Scientific Selection of Jews, Gypsies, and Others, Germany 1933-1945. Oxford: Oxford University Press; 1988.

59. SüssW.Der"Volkskörper"imKrieg.Gesundheitspolitik, Gesundheitsverhältnisse und Krankenmord im nationalsozialistischen Deutschland 1939-1945. Munich: Oldenbourth 2003. [In German]

60. Kogon E, Langbein H, Rückler A. Nationalsozialistische Massentötungen durch Giftgas: Eine Dokumentation. Frankfurt: S. Fischer Verlag; 1983. [In German]

61. Faulstich H. Die Zahl der "Euthanasie"-Opfer. Frankfurt: Campus; 2000. [In German]

62. Gabriel E, Wolfgang N. Von der Zwangssterilisierung zur Ermordung. Vienna: Böhlau; 2002. [In German]

63. Mader ET. Das erzwungene Sterben von Patienten der Heil- und Pflegeanstalt Kaufbeuren-Irse zwischen 1940 und 1945 nach Dokumenten und Berichten von Augenzeugen. 2nd. ed. Blöcktach: Verlag an der Säge; 1985. [In German]

64. Strous R. Extermination of the Jewish mentally-ill during the Nazi era--the "doubly cursed". Isr J Psychiatry Relat Sci. 2008;45:247-56.

65. Lifton RJ. Medicalized killing in Auschwitz. Psychiatry. 1982;45:283-97.

66. Zeidman LA. Neuroscience in Nazi Europe part I: eugenics, human experimentation, and mass murder. Can J Neurol Sci. 2011;38:696-703. 
67. Siemen H-L. Menschen blieben auf der Strecke. Psychiatrie zwischen Reform und Nationalsozialismus. Gütersloh: Paranus; 1987. [In German]

68. Kersting F-W, Schmuhl, H-W, editors. Quellen zur Geschichte der Anstaltspsychiatrie in Westfalen. Paderborn: Schöningh 2004. [In German]

69. Hohendorf G, Rotzoll M, Richter P, Eckart W, Mundt C. Die Opfer der nationalsozialistischen "Euthanasie-Aktion T4" Erste Ergebnisse eines Projektes zur Erschliessung von Krankenakten getoteter Patienten im Bundesarchiv Berlin. [Victims of Nazi euthanasia, the so-called T4 action. First results of a project at the German Federal Archives to disclose records of killed patients]. Nervenarzt. 2002;73:1065-74. [In German]

70. Alexander L. The molding of personality under dictatorship; the importance of the destructive drives in the socio-psychological structure of Nazism. J Crim Law Criminol. 1949;40:3-27.

71. Andorno R. Global bioethics at UNESCO: in defence of the Universal Declaration on Bioethics and Human Rights. J Med Ethics. 2007;33:150-4.

72. Thomasma DC. Proposing a new agenda: bioethics and international human rights. Camb Q Healthc Ethics. 2001;10:299-310.

73. Beyleveld D, Brownsword, R. Human dignity in bioethics and biolaw. Oxford: Oxford University Press; 2001.

74. Andorno R. Human dignity and human rights as a common ground for a global bioethics. J Med Philos. 2009;34:223-40.

75. Nordenfelt L. The varieties of dignity. Health Care Anal. 2004;12:69-81; discussion 83-9.

76. Giubilini A, Minerva F. After-birth abortion: why should the baby live? J Med Ethics. 2013;39:261-3.

77. Thom A, Caregorodcev GI. Medizin unterm Hakenkreuz. Berlin: VEB Verlag Volk und Gesundheit; 1989. [In German]

78. Hohendorf GM, Magull-Seltenreich A. Von der Heilkunde zur Massentötung: Medizin im Nationalsozialismus. Heidelberg: Wundehorn; 1990. [In German]

79. Pury CLS, Lopez SJ (editors). The Psychology of Courage: Modern Research on an Ancient Virtue. Washington, DC: American Psychopathological Association; 2010.

80. Kidder RM. Moral Courage. Taking Action When Your Values are Put to the Test. New York, NY: William Morrow; 2006. 